\title{
QUALITATIVE ANALYSIS OF VERNALIZATED SEMI-NOBLE GARLIC CULTIVARS IN WESTERN RIO GRANDE DO NORTE STATE, BRAZIL ${ }^{1}$
}

\author{
RAFAELLA RAYANE MACEDO DE LUCENA ${ }^{2 *}$, MARIA ZULEIDE DE NEGREIROS ${ }^{2}$, PATRÍCIA LÍGIA DANTAS \\ DE MORAIS ${ }^{2}$, WELDER DE ARAÚJO RANGEL LOPES ${ }^{2}$, ALINNE MENEZES SOARES ${ }^{3}$
}

\begin{abstract}
Garlic is a vegetable that has economic and social relevance in Brazil. Rio Grande do Norte is among the consumer states, however, despite having regions with favorable conditions for growing garlic, it depends on imports of this product to meet its demand. The introduction of cultivars that have high yield and quality, and the adjustments in vernalization technology, which is a key issue for adaptation of new cultivars, are mechanisms that can contribute to garlic revitalization in areas previously producing this vegetable. Therefore, the objective of this work was to assess the quality characteristics of semi-noble garlic cultivars subjected to different bulb-seed pre-planting vernalization periods in two counties of the Western Mesoregion of Rio Grande do Norte State (RN), Brazil. Two experiments were simultaneously conducted in Barauna RN and Governador Dix-sept Rosado RN, from April to November, 2012. A complete randomized block experimental design was used with four replications. The treatments were arranged in split-plot design, with the plots consisted of cultivars (Gigante-do-Nucleo and BRS-Hozan) and subplots consisted of bulb-seed preplanting vernalization $\left(4 \pm 1^{\circ} \mathrm{C}\right)$ periods $(0,10,20$ and 30 days). The evaluations consisted of bulb diameter, $\mathrm{pH}$, titratable acidity, soluble solids, total soluble sugars, reducing sugars, pungency, total solids and industrial index. The use of 10-day bulb-seed pre-planting vernalization increased the semi-noble garlic quality produced in Barauna and Governador Dix-sept Rosado. The cultivars Gigante-do-Nucleo and BRS-Hozan presented good prospects for industrialization, with good characteristics of flavor and aroma.
\end{abstract}

KEYWORDS: Allium sativum L. Refrigeration. Quality. Industrial index.

\section{ANÁLISE QUALITATIVA DE CULTIVARES DE ALHO SEMI-NOBRE VERNALIZADO NA MESORREGIÃO OESTE POTIGUAR}

\begin{abstract}
RESUMO - O alho é uma hortaliça de relevância econômica e social no Brasil. Entre os estados consumidores, o Rio Grande do Norte, especialmente, apesar de apresentar regiões com condições favoráveis ao cultivo de alho, depende da importação deste produto para atender a sua demanda. A introdução de cultivares mais produtivas e de qualidade, e ajustes da tecnologia de vernalização, ponto fundamental para adaptação de novas cultivares, são mecanismos que podem contribuir para revitalização do alho em regiões, anteriormente produtoras desta hortaliça. Com o presente trabalho, objetivou-se avaliar as características qualitativas de cultivares de alho semi-nobre, submetidas a diferentes períodos de vernalização pré-plantio dos bulbos-semente em dois municípios da Mesorregião Oeste Potiguar. A pesquisa constou de dois experimentos desenvolvidos, simultaneamente, em Baraúna/RN e Governador Dix-sept Rosado/RN, entre os meses de abril e novembro de 2012. O delineamento experimental foi o de blocos casualizados com quatro repetições. Os tratamentos foram dispostos em parcelas subdivididas, sendo as parcelas representadas pelas cultivares Gigante do Núcleo e BRS Hozan e as subparcelas constituídas pelos períodos de vernalização à $4 \pm 1{ }^{\circ} \mathrm{C}$ : $0,10,20$ e 30 dias. Foram avaliados: diâmetro de bulbos, $\mathrm{pH}$, acidez titulável, sólidos solúveis, açúcares solúveis totais, açúcares redutores, pungência, sólidos totais e índice industrial. O uso de 10 dias de vernalização pré-plantio dos bulbossemente possibilitou incrementos na qualidade do alho semi-nobre produzido em Baraúna e Governador Dixsept Rosado. As cultivares Gigante do Núcleo e BRS Hozan mostraram-se com boas perspectivas para industrialização, apresentando boas características de sabor e aroma.
\end{abstract}

PALAVRAS-CHAVE: Allium sativum L. Frigorificação. Qualidade. Índice industrial.

\footnotetext{
*Corresponding author.

${ }^{1}$ Received for publication in $01 / 26 / 2015$; accepted in 03/09/2016 .

Paper extracted from the doctoral thesis of the first author.

${ }^{2}$ Department of Plant Sciences, Universidade Federal Rural do Semi-Árido, Mossoró, RN, Brazil; rafaellarayane@hotmail.com zuleide@ufersa.edu.br, plmorais@hotmail.com,welder.lopes@hotmail.com.

${ }^{3}$ Agricultural Science Center, Universidade Federal da Paraíba, Areia, PB, Brazil; alinne_menezes@hotmail.com.
} 


\section{INTRODUTION}

Most of the garlic produced in Brazil is marketed in natura, however, industrial products such as garlic pastes and, to a lesser extent, dehydrated garlic have been introduced to the market with great acceptance (SOARES, 2013).

Despite the importance of this crop in Brazil, the country is the world's largest importer of garlic, with China and Argentina as its main suppliers (LUCINI, 2014). On the other hand, the national product supply in the domestic market has shown a gradual increase in recent years, thanks to the development of new technologies and cultivars in producing areas (OLIVEIRA et al., 2010; GUTIERREZ; ROCHA, 2014).

The adoption of vernalization has enabled to plant garlic cultivars from the south of Brazil in regions where the thermo-photoperiodic conditions do not meet the plant's requirements (MACÊDO et al., 2009). However, differences between cultivars, regarding reactions to vernalization, can be seen through aspects related to post-harvest conservation and commercial quality of garlic bulbs (MUELLER; BIASI, 1989; PEREIRA et al., 2003).

The vernalization technique consists in subjecting the bulb-seed at low temperature for a certain period before planting, thus stimulating the accumulation of hormones, modifying the hormonal balance, which includes increasing free gibberellins and cytokinins. These chemical changes, which are favored by low temperatures, stimulate biochemical and morphological changes. Morphological changes by vernalization are related to the photoperiodic requirements of cultivars (SCOTTON, 2007).

Due to the increasing demand of the consumer food market, techniques used in preplanting, such as vernalization, and during the field phase, allowing the garlic to reach the market with quality for consumption are essential.

In general, to assess the garlic quality, qualitative analyzes are conducted, which consider attributes such as titratable acidity, $\mathrm{pH}$, soluble solids, soluble solids / titratable acidity ratio, total solids, total soluble sugars, reducing sugars, pungency, industrial index, among others (CHAGAS et al., 2003; CHITARRA; CHITARRA, 2005; SOARES, 2013).

The information generated through qualitative analysis of garlic can indicate whether the product is more appropriate for in natura consumption or industry, the highest post-harvest storage capacity and also, according to Oliveira et al. (2003), the best time to carry out the harvest.

Rio Grande do Norte State (RN), in particular the county of Governador Dix-sept Rosado, was a garlic producer and exporter, supplying neighboring states such as Pernambuco, Ceara, Maranhao and Para, by the end of the 1980s (HONORATO et al., 2013), however, there are no researches on crops of this region in the literature, especially regarding the garlic quality.

In this context, the objective of this work was to assess quality characteristics of garlic cultivars subjected to different bulb-seed pre-planting vernalization periods in two counties of the Western Mesoregion of Rio Grande do Norte State (RN), Brazil.

\section{MATERIAL AND METHODS}

Two experiments were simultaneously conducted and equally managed in two locations of the Western Mesoregion of Rio Grande do Norte State, Brazil, from April to November, 2012.

The first experiment was conducted at Santa Luzia Farm, Community of Juremal, county of Barauna $\mathrm{RN}$, in a soil classified as medium textured haplic Cambisol (EMBRAPA, 2006), which had, according to chemical analysis of soil samples collected at $0-20 \mathrm{~cm}$ of depth, the following characteristics: $\mathrm{pH} \mathrm{H}_{2} \mathrm{O}=5.80, \mathrm{P}=2.70 \mathrm{mg} \mathrm{dm} \mathrm{dm}^{-3}$, $\mathrm{K}=216.00 \mathrm{mg} \mathrm{dm}{ }^{-3}, \mathrm{Na}=5.80 \mathrm{mg} \mathrm{dm}^{-3}, \mathrm{Ca}=4.69$ $\mathrm{cmol}_{\mathrm{c}} \mathrm{dm}^{-3}, \mathrm{Mg}=0.93 \mathrm{cmol}_{\mathrm{c}} \mathrm{dm}^{-3}, \mathrm{Al}=0.00 \mathrm{cmol}_{\mathrm{c}} \mathrm{dm}^{-}$ 3 and $\mathrm{MO}=7.79 \mathrm{~g} \mathrm{~kg}^{-1}$. Barauna $\left(5^{\circ} 04^{\prime} \mathrm{S}, 37^{\circ} 37^{\prime} \mathrm{W}\right.$ and $120 \mathrm{~m}$ of altitude), has photoperiod with little variation along the year, around 12 hours. The mean temperature and relative humidity measured during the experimental period were $26.6^{\circ} \mathrm{C}$ and $59.1 \%$, respectively.

The second experiment was conducted at Santana Farm, county of Governador Dix-sept Rosado RN, in a soil classified as medium textured eutrophic Fluvisol (EMBRAPA, 2006), which had, according to chemical analysis of soil samples collected at $0-20 \mathrm{~cm}$ of depth, the following characteristics: $\mathrm{pH} \mathrm{H}_{2} \mathrm{O}=7.78, \mathrm{P}=382.40 \mathrm{mg} \mathrm{dm}^{-3}$, $\mathrm{K}=153.2 \mathrm{mg} \mathrm{dm}{ }^{-3}, \mathrm{Na}=16.10 \mathrm{mg} \mathrm{dm}^{-3}, \mathrm{Ca}=7.03$ $\mathrm{cmol}_{\mathrm{c}} \mathrm{dm}^{-3}, \mathrm{Mg}=0.80 \mathrm{cmol}_{\mathrm{c}} \mathrm{dm}^{-3}, \mathrm{Al}=0.00 \mathrm{cmol}_{\mathrm{c}} \mathrm{dm}^{-}$ 3 and $\mathrm{MO}=10.90 \mathrm{~g} \mathrm{~kg}^{-1}$. Governador Dix-sept Rosado ( $5^{\circ} 27^{\prime} \mathrm{S}, 37^{\circ} 31^{\prime} \mathrm{W}$ and $34 \mathrm{~m}$ of altitude) has also photoperiod with little variation along the year, around 12 hours. The mean temperature and relative humidity measured during the experimental period were $28.6^{\circ} \mathrm{C}$ and $55.9 \%$, respectively.

A complete randomized block experimental design was used with four replications. The treatments were arranged in split-plot design, in which the plots consisted of the cultivars (Gigantedo-Nucleo and BRS-Hozan) and subplots consisted of the bulb-seed pre-planting vernalization periods $(0,10,20$ and 30 days).

The cultivars Gigante-do-Nucleo and BRSHozan are from the semi-noble group, whose characteristics are average cycle, harvest from 130 to 150 days after planting, round bulbs with cream colored tunics with anthocyanin stretch marks that give a purplish appearance to the bulb, bulbs with eight to fifteen bulbils, pink bulbils, elongated bulbils and bulbils perfectly embedded in the bulb 
structure.

The bulb-seeds were subjected to vernalization process (cold storage at a temperature of $4 \pm 1{ }^{\circ} \mathrm{C}$ and relative humidity of $75 \pm 5 \%$ ) before planting, which was performed at May 18 (Barauna) and 21 (Governador Dix-sept Rosado), 2012. The bulb-seeds from each treatment were subjected to the cold chamber in an order that allowed the planting of the bulbils in all subplots at the same time. After the vernalization period, the bulb-seeds were retrieved from the cold chamber for threshing and planting.

The subplot beds were $0.20 \mathrm{~m}$ high, $1.0 \mathrm{~m}$ wide and $2.0 \mathrm{~m}$ long, with five planting rows. The bulbils were planted at a depth of $0.05 \mathrm{~m}$, spaced $0.20 \mathrm{~m}$ between rows and $0.10 \mathrm{~m}$ between plants, with total area of $2.0 \mathrm{~m}^{2}$ and evaluation area of 1.08 $\mathrm{m}^{2}$, totaling 100 plants and 54 assessed plants per subplot.

Soil preparation consisted of plowing and harrowing, followed by preparation of the beds. Fertilization at planting was performed based on the soil analysis and suggestions from Cavalcanti (2008) and Resende et al. (2004) for the garlic crop in both locations. Fertilization at planting was performed with $40 \mathrm{Mg} \mathrm{ha}^{-1}$ Pole Fertil (based on cattle and chicken manure), $30 \mathrm{~kg} \mathrm{ha}^{-1} \mathrm{~N}$ (ammonium sulfate), $60 \mathrm{~kg} \mathrm{ha}^{-1} \mathrm{P}_{2} \mathrm{O}_{5}$ (single superphosphate), $20 \mathrm{~kg} \mathrm{ha}^{-1}$ $\mathrm{K}_{2} \mathrm{O}$ (potassium chloride), $15 \mathrm{~kg} \mathrm{ha}^{-1} \mathrm{Mg}$ (magnesium sulfate) $7 \mathrm{~kg} \mathrm{ha}^{-1} \mathrm{Zn}$ (zinc sulphate) and $1.7 \mathrm{~kg} \mathrm{ha}{ }^{-1} \mathrm{~B}$ (boric acid). Two topdressing fertilization applications were performed, 30 days after planting with $30 \mathrm{~kg} \mathrm{ha}^{-1} \mathrm{~N}$ (urea) and $20 \mathrm{~kg} \mathrm{ha}^{-1}$ of $\mathrm{K}_{2} \mathrm{O}$ (potassium chloride), and 60 days after planting with $30 \mathrm{~kg} \mathrm{ha}^{-1} \mathrm{~N}$ (urea).

A micro-sprinkler irrigation system was used with two micro-sprinklers per subplot, water flow rate of $27 \mathrm{~L} \mathrm{~h}^{-1}$ and pressure of $200 \mathrm{kPa}$, estimating the amount of water applied according to crop evapotranspiration (ALLEN et al., 1998), taking into account the reference evapotranspiration $\left(\mathrm{ET}_{0}\right)$ and the crop $\mathrm{Kc}$ for each development stage. Tensiometers were installed at 0.15 and $0.30 \mathrm{~m}$ deep, with two replications for each experiment, in order to monitor the soil moisture during the experimental period.

Prevention and control of diseases, such as the purple blotch was performed with a Mancozeb based product (Manzate ${ }^{\circledR} 2.5 \mathrm{~g} \mathrm{~L}^{-1}$ ) sprayed with 7day intervals. Pest control, such as thrips and mites was performed with alternate 15-day interval spraying of clorfernapir (Pirate ${ }^{\circledR} 0.5 \mathrm{~mL} \mathrm{~L}^{-1}$ ) and deltamethrin (Decis ${ }^{\circledR}, 0.3 \mathrm{~mL} \mathrm{~L}^{-1}$ ). Weed control was performed manually in the subplots and with hoes between the beds, always maintaining a clean area for the plants.

The harvest was performed as the plants were showing maturation signs (yellowing and drying in the leaves in about $2 / 3$ of the shoots). After harvesting, the bulbs were subjected to a curing process at sunlight for three days. Therefore, the plants were laid out in rows, so that the leaves of a plant would cover the plant bulbs of the next line, protecting them from direct sunlight. Subsequently, the bulbs were subjected to a curing process at shadow in a wide and ventilated area for seven days. After the curing process, the bulbs were cleaning and the shoots were removed ( $1 \mathrm{~cm}$ from the bulbs) as well as the stem roots.

After cleaning, the bulbs were threshed, and a sample of 100 bulbils per subplot was taken. This material was sent to the post-harvest laboratory of the Federal Rural University of the Semi-Arid Region (UFERSA) for analysis. The bulbils were peeled and ground in a processor to a pasty and homogeneous consistency. This material was filtered through a $100 \%$ polyester fabric, in order to separate the juice and perform the qualitative analysis. The analyzed characteristics were:

a) Bulb diameter - found by measuring the bulbs using a caliper rule, at the time of harvest, considering the bulb average transversal diameters (mm).

b) Power of Hydrogen ( $\mathbf{p H}$ ) - found by measuring with a potentiometer with automatic temperature adjustment, calibrated in $\mathrm{pH} 7.0$ and $\mathrm{pH} 4.0$ buffer solutions, according to recommendations of physicochemical methods for food analysis (IAL, 2005).

c) Titratable acidity - found by using $1 \mathrm{~g}$ of garlic paste with distilled water, and three drops of phenolphthalein alcohol $1 \%$, resulting in a $50 \mathrm{~mL}$ solution, for titration, which was then performed with a $\mathrm{NaOH}$ solution $(0.1 \mathrm{M})$ until the turning point characterized by the pinkish color. The results were expressed in $\mathrm{mEq} \mathrm{H} 3 \mathrm{O}+/ 100 \mathrm{~g}$ (IAL, 2005).

d) Soluble solids - found directly from the homogenized garlic juice through readings on a digital refractometer (PR-100 model, Palette Atago Co, LTD. Japan) with automatic temperature compensation. The results were expressed as \% ( ${ }^{\circ}$ Brix) according to the methodology proposed by the AOAC (2002).

e) Total soluble sugars - found according to the method used by Yemm e Willis (1954), thus, $0.5 \mathrm{~g}$ of the garlic paste was diluted in distilled water in a 100 $\mathrm{mL}$ volumetric flask, and filtered to obtain the extract. Then, $30 \mu \mathrm{L}$ of the extract and $970 \mu \mathrm{L}$ of distilled water was placed in a test tube. These tubes were subjected to an ice bath, remaining there while the $2 \mathrm{~mL}$ of anthrone reagent was added. Subsequently, the tubes were vortexed and immediately returned to the ice bath, then the tubes were subjected to boiling water bath for 8 minutes. They were then cooled in ice water. The readings were performed through a spectrophotometer at 620 $\mathrm{nm}$. The results were expressed in $\mathrm{g}$ per $100 \mathrm{~g}$ of pulp.

f) Reducing sugars - found according to the method used by Miller (1959). A sample of $4.0 \mathrm{~g}$ of the paste was diluted in $50 \mathrm{~mL}$ of water in a volumetric flask, 
then filtered to obtain the extract. An aliquot of 1.5 $\mathrm{mL}$ of this extract was added to a test tube with $1 \mathrm{~mL}$ of dinitro-salicylic (DNS) reagent. The tubes were stirred and subjected to a boiling bath to boil for five minutes. Then, $7.5 \mathrm{~mL}$ of distilled water was added and the tubes were cooled in an ice bath for analysis. The results were expressed in percentage of glucose per $100 \mathrm{~g}$ of pulp.

g) Pungency - quantified as a function of pyruvic acid content using the colorimetric method described by Schwimmer and Weston (1961), thus, $0.2 \mathrm{~mL}$ of garlic juice, $1.5 \mathrm{~mL}$ of trichloroacetic acid $(5 \%)$ and $18.3 \mathrm{~mL}$ of distilled water were placed to an Erlenmeyer flask and stirred. Then, $1 \mathrm{~mL}$ of this sample was placed in a tube test, in which was added $1 \mathrm{~mL}$ of 2,4-dinitrophenylhydrazine (DNPH) and 1 $\mathrm{mL}$ of distilled water, and stirred in vortex. The test tubes were placed in a water bath at $37^{\circ} \mathrm{C}$ for 10 minutes and then immediately cooled in water with ice. Subsequently, $5 \mathrm{~mL}$ of $\mathrm{NaOH} 0.6 \mathrm{~N}$ was added, stirred in vortex and left for five minutes to the yellow color develop. The absorbance was read in a spectrophotometer at $420 \mathrm{~nm}$, using sodium pyruvate as standard. The pungency was assessed by the sodium pyruvate standard curve at seven concentrations $(0.0,0.2,0.4,0.6,0.8,1.0,1.2 \mathrm{mmol}$ $\left.\mathrm{L}^{-1}\right)$. The results were expressed in $\mu \mathrm{mol}$ of pyruvic acid per $\mathrm{mL}$ of garlic juice.

h) Total solids - found by placing the bulbils in an oven with forced air circulation at a temperature of $65^{\circ} \mathrm{C}$ to a constant dry weight, and calculating by the difference between 100 and the moisture content of bulbils. The results are expressed in grams of total solids per $100 \mathrm{~g}$ of garlic, according to the recommendations of the physicochemical methods for food analysis (IAL, 2005).

i) Industrial index - assessed by the formula: $\mathrm{Ii}=(\mathrm{x}$ Total solids pyruvic acid)/100, according to Carvalho et al. (1991).

The experiment data were subjected to onefactor analysis of variance using the software SISVAR v.5.3 (FERREIRA, 2007), and regression using the Table Curve 2D v5.01 software (JANDEL SCIENTIFIC, 1991). The comparison of means was performed by the Student's $t$ test for planting locations and cultivars, and Tukey's test for vernalization periods, in this case, when a significant equation model was not found (at $5 \%$ of significance level).

\section{RESULTS AND DISCUSSION}

The interactions between vernalization periods, cultivars and planting locations presented significant effects in the characteristics $\mathrm{pH}$, titratable acidity, soluble solids, reducing sugars, pungency, total solids and industrial index. The interaction between vernalization periods and planting locations and between cultivars and planting locations influenced the diameter of bulbs. The interaction between cultivars and planting locations significantly influenced the total soluble sugars.

The structural equation model did not fit the data and did not explain the characteristics of bulbs diameter, $\mathrm{pH}$, titratable acidity, reducing sugars, pungency and industrial index according to the vernalization periods.

The cultivars produced bulbs of larger diameter without bulb-seed vernalization in Barauna. This average decreased as the vernalization period increased (Table 1). This result was also found by Silva et al. (2000) with the cultivars Gigante-deLavinia, Jureia, Gigante-Roxo, Gigante-Curitibanos and Gravata, indicating that this technique is detrimental to the studied cultivars, since the increase in vernalization time (0-40 days) caused an increase in the non-commercial production, i.e., increase the number of small bulbs with diameter (less than 32 $\mathrm{mm})$.

In Governador Dix-sept Rosado, the largest diameter of bulbs was found with bulb-seed vernalization for 10 days, with the lowest average after this period (Table 1). This difference in diameter of bulbs between planting locations can be related to the influence of climatic factors of each location, thus, in locations where temperatures are higher, as in Governador Dix-sept Rosado, the need for vernalization is greater, in order to improve the crop production and bulb size. The treatment without vernalization was the only one that had significant difference between planting locations, Barauna stood out with average bulb diameter of $42.1 \mathrm{~mm}$.

Table 1. Average values of semi-noble garlic bulb diameter $(\mathrm{mm})$ according to vernalizated periods in Barauna $\mathrm{RN}$ and Governador Dix-sept Rosado RN, Brazil.

\begin{tabular}{|c|c|c|c|c|}
\hline \multirow[t]{2}{*}{ Planting locations } & \multicolumn{4}{|c|}{ Vernalization periods (days) } \\
\hline & 0 & 10 & 20 & 30 \\
\hline Barauna RN & 42.1 & 33.7 & 29.9 & 29.7 \\
\hline Gov. Dix-sept Rosado RN & 31.8 & 34.8 & 29.2 & 28.5 \\
\hline
\end{tabular}

Regarding the effects of cultivars in each planting location, the Gigante-do-Nucleo presented higher bulb diameter compared to the BRS-Hozan only in Governador Dix-sept Rosado, while Barauna presented bulb average diameter of $34.15 \mathrm{~mm}$. Moreover, the Gigante-do-Nucleo presented similar bulb diameter in both locations, while BRS-Hozan had larger bulb diameters in Barauna (Table 2). 
These results are similar to those found by Oliveira et al. (2010) in Diamantina, State of Minas Gerais
(MG), which found average bulb diameter of 36.75 $\mathrm{mm}$ for Gigante-do-Nucleo and $31.50 \mathrm{~mm}$ for BRSHozan.

Table 2. Average values of bulb diameter $(\mathrm{mm})$ of semi-noble garlic cultivars according to planting locations (Barauna RN and Governador Dix-sept Rosado RN, Brazil).

\begin{tabular}{lcc}
\hline Cultivars & \multicolumn{2}{c}{ Planting locations } \\
\cline { 2 - 3 } & Barauna RN & Gov. Dix-sept Rosado RN \\
\hline Gigante-do-Nucleo & 33.8 & 33.9 \\
BRS-Hozan & 34.5 & 27.9 \\
\hline Minimum significant difference between cultivars $=1.89$. Student's t test (LSD), $\mathrm{p}<0.05$. \\
Minimum significant difference between planting locations $=1.89$. Student's t-test (LSD), $<<0.05$. \\
\hline
\end{tabular}

Regarding the vernalization periods of cultivars in each planting location, the highest average $\mathrm{pH}$ was found in the treatment with 20 days of vernalization (DV) for the cultivar Gigante-doNucleo in Barauna. However, in Governador DixSept Rosado both cultivars presented statistically similar values (Table 3). Higher values were found by Mota et al. (2003), in Lavras MG, for the cultivars Amarante, Cateto-Roxo, Gigante-Roxao, Gigante-Roxo, Gravata and Gigante-Curitibanos, with $\mathrm{pH}$ ranging from 6.60 to 7.06 .

Table 3. Average values of $\mathrm{pH}$, titratable acidity, reducing sugars, pungency and industrial index of vernalizated semi-noble garlic cultivars in Barauna and Governador Dix-sept Rosado RN, Brazil.

\begin{tabular}{|c|c|c|c|c|c|}
\hline \multirow[t]{2}{*}{ Planting locations } & \multirow[t]{2}{*}{ Cultivars } & \multicolumn{4}{|c|}{ Vernalization periods (days) } \\
\hline & & 0 & 10 & 20 & 30 \\
\hline \multirow{3}{*}{ Barauna RN } & & \multicolumn{4}{|c|}{$\mathrm{pH}$} \\
\hline & Gigante-do-Nucleo & 6.16 & 6.14 & 6.38 & 6.01 \\
\hline & BRS-Hozan & 5.99 & 6.04 & 6.08 & 6.05 \\
\hline \multirow[t]{2}{*}{ Gov. Dix-sept Rosado RN } & Gigante-do-Nucleo & 5.95 & 6.05 & 6.02 & 6.02 \\
\hline & BRS-Hozan & 6.02 & 5.97 & 6.06 & 6.07 \\
\hline $\mathrm{DMS}_{\mathrm{DV}}=0.11$ & $\mathrm{DMS}_{\mathrm{L}}=0.08$ & & & & \\
\hline \multirow{3}{*}{ Barauna RN } & & \multicolumn{4}{|c|}{ Titratable acidity $\left(\mathrm{mEq} \mathrm{H}_{3} \mathrm{O}^{+} / 100 \mathrm{~g}\right)$} \\
\hline & Gigante-do-Nucleo & 6.30 & 6.95 & 5.96 & 5.79 \\
\hline & BRS-Hozan & 6.79 & 6.70 & 8.44 & 4.64 \\
\hline \multirow[t]{2}{*}{ Gov. Dix-sept Rosado RN } & Gigante-do-Nucleo & 4.85 & 5.82 & 5.96 & 5.63 \\
\hline & BRS-Hozan & 6.54 & 5.82 & 6.21 & 6.33 \\
\hline $\mathrm{DMS}_{\mathrm{DV}}=0.53$ & $\mathrm{DMS}_{\mathrm{L}}=0.40$ & & & & \\
\hline \multirow{3}{*}{ Barauna RN } & & \multicolumn{4}{|c|}{ Reducing sugars (\%) } \\
\hline & Gigante-do-Nucleo & 0.38 & 0.37 & 0.38 & 0.31 \\
\hline & BRS-Hozan & 0.48 & 0.44 & 1.10 & 0.75 \\
\hline \multirow[t]{2}{*}{ Gov. Dix-sept Rosado RN } & Gigante-do-Nucleo & 0.34 & 0.31 & 0.26 & 0.30 \\
\hline & BRS-Hozan & 0.68 & 0.39 & 0.69 & 0.83 \\
\hline $\mathrm{DMS}_{\mathrm{DV}}=0.13$ & $\mathrm{DMS}_{\mathrm{L}}=0.11$ & & & & \\
\hline \multirow{3}{*}{ Barauna $\mathrm{RN}$} & & \multicolumn{4}{|c|}{ Pungency ( $\mu$ Moles of pyruvic acid $\mathrm{mL}^{-1}$ ) } \\
\hline & Gigante-do-Nucleo & 95.59 & 97.21 & 90.98 & 87.72 \\
\hline & BRS-Hozan & 80.69 & 88.14 & 80.23 & 90.45 \\
\hline \multirow[t]{2}{*}{ Gov. Dix-sept Rosado RN } & Gigante-do-Nucleo & 76.32 & 80.56 & 78.38 & 73.45 \\
\hline & BRS-Hozan & 75.85 & 75.72 & 67.32 & 76.10 \\
\hline $\mathrm{DMS}_{\mathrm{DV}}=6.65$ & $\mathrm{DMS}_{\mathrm{L}}=5.94$ & & & & \\
\hline \multirow{3}{*}{ Barauna RN } & & \multicolumn{4}{|c|}{ Industrial index } \\
\hline & Gigante-do-Nucleo & 25.42 & 28.46 & 27.82 & 28.56 \\
\hline & BRS-Hozan & 27.22 & 30.68 & 27.31 & 36.67 \\
\hline \multirow[t]{2}{*}{ Gov. Dix-sept Rosado RN } & Gigante-do-Nucleo & 22.28 & 23.05 & 21.41 & 23.90 \\
\hline & BRS-Hozan & 26.42 & 26.91 & 25.15 & 28.07 \\
\hline $\mathrm{DMS}_{\mathrm{DV}}=2.72$ & $\mathrm{DMS}_{\mathrm{L}}=2.03$ & & & & \\
\hline $\begin{array}{l}\mathrm{DMS}_{\mathrm{DV}} \text { (Minimum significant diffe } \\
\mathrm{DMS}_{\mathrm{C}} \text { (Minimum significant differ } \\
\mathrm{DMS}_{\mathrm{L}} \text { (Minimum significant differ }\end{array}$ & $\begin{array}{l}\text { between vernalizatio } \\
\text { petween cultivars); St } \\
\text { petween planting loca }\end{array}$ & $\begin{array}{l}\text { ); Tuk } \\
\text { test (L }\end{array}$ & $\begin{array}{l}\mathrm{p}<0.05 \\
0.05\end{array}$ & & \\
\hline
\end{tabular}

$\mathrm{pH}$ is a key indicative of vegetable flavor, which usually has an inverse relation to acidity, however, the buffering capacity of some juices causes large variations in titratable acidity, without significant variations in $\mathrm{pH}$ (CHITARRA;
CHITARRA, 2005). This characteristic was found in the present study; the high buffering capacity of garlic paste caused little variation in $\mathrm{pH}$, ranging from 5.95 to 6.38 , in contrast to the higher values found for acidity. 
Regarding the titratable acidity depending on vernalization periods, cultivars and planting locations, the highest average acidity was found for the cultivar Gigante-do-Nucleo in Barauna when the bulb-seeds were vernalized for 10 days, and in Governador Dix-sept Rosado when vernalizated for 10, 20 and $30 \mathrm{DV}$. The cultivar BRS-Hozan had the highest average acidity with $20 \mathrm{DV}$ in Barauna, and in the treatments without vernalization and with 20 and $30 \mathrm{DV}$ in Governador Dix-sept Rosado, the last two being similar to $10 \mathrm{DV}$ (Table 3 ).

Regarding the titratable acidity depending on cultivars, significant differences were found in Barauna in treatments without vernalization and with 20 and $30 \mathrm{DV}$, especially for BRS-Hozan that had $8.44 \mathrm{mEq} \mathrm{H} \mathrm{O}^{+} / 100 \mathrm{~g}$ with $20 \mathrm{DV}$, and for Gigantedo-Nucleo with $5.79 \mathrm{mEq} \mathrm{H} \mathrm{O}^{+} / 100 \mathrm{~g}$ with $30 \mathrm{DV}$.

BRS-Hozan had the highest titratable acidity in treatments without vernalization and with $30 \mathrm{DV}$ in Governador Dix-sept Rosado, with no significant differences between cultivars with 10 and $20 \mathrm{DV}$ (Table 3). The cultivars had higher titratable acidity in Barauna, probably due to less intense metabolism caused by the temperature of this county, which was lower than the temperature in Governador Dix-sept Rosado.

Chagas et al. (2003) assessed quality

A Barauna RN

B

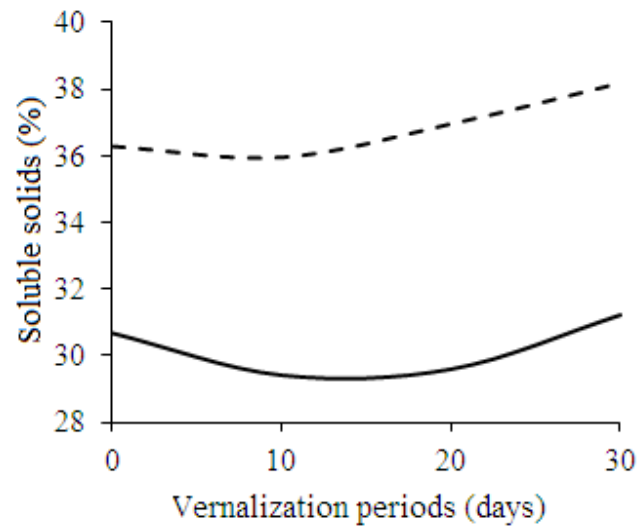

- Gigante-do-Nucleo $\hat{y}=30.6655^{*}-0.1999 * x+0.0073 * x^{2} R^{2}=0.99 *$ - - - BRS-Hozan $\hat{y}=36.2877 *+0.1974 * x-0.7308 * x^{0.5} R^{2}=0.95 *$ characteristics of garlic cultivars and stated that the acidity is an important factor for industrialization, since the higher the acidity, the better the garlic industrial characteristics. Soares (2013) studying garlic cultivars (Amarante, Branco-Mossoro, CatetoRoxo, Catigua, Caturra, Cntenário, Chileno-PR, Chines-Real, Gravata, Mexicano and MoranoArequipeno) in Governador Dix-sept Rosado without vernalization, found titratable acidity from 5.33 to $7.76 \mathrm{mEq} \mathrm{H} 3 \mathrm{O}+/ 100 \mathrm{~g}$, thus within the range values found in the present study.

Regarding the soluble solids depending on vernalization periods, the cultivars Gigante-doNucleo and the BRS-Hozan presented different results in both planting locations. BRS-Hozan presented exponential and decreasing linear effects depending on vernalization periods, respectively in Barauna (Figure 1A) and Governador Dix-sept Rosado (Figure 1B), reaching maximum estimated values of $38.20 \%$ at $30 \mathrm{DV}$ in Barauna and $38.40 \%$ without vernalization in Governador Dix-sept Rosado. Cultivar Gigante-do-Nucleo presented quadratic behavior in both locations, with maximum estimated values of $31.21 \%$ in Barauna with $30 \mathrm{DV}$, and $32.29 \%$ in Governador Dix-Sept Rosado with 23 DV.

Governador Dix-sept Rosado RN

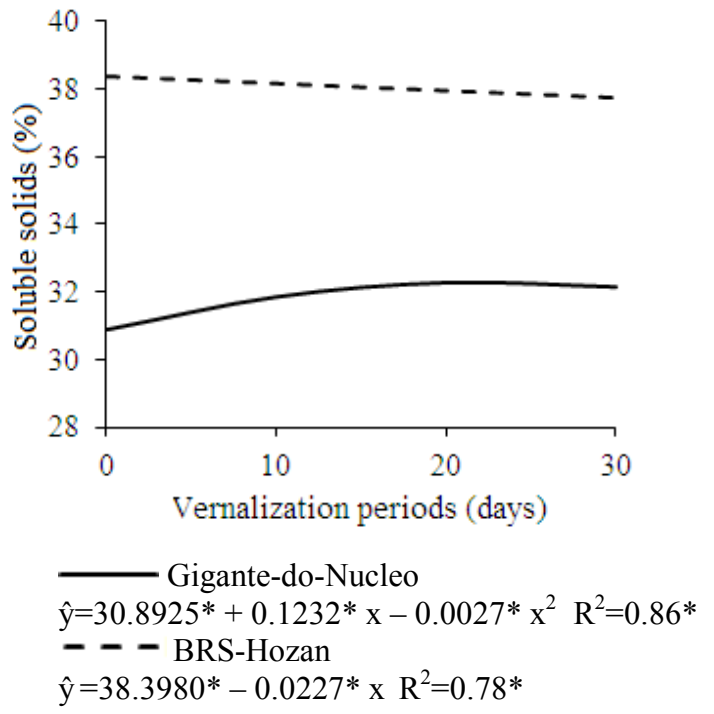

Figure 1. Soluble solids of vernalizated semi-noble garlic cultivars in Barauna RN (A) and Governador Dix-sept Rosado RN (B), Brazil. * = significant at $5 \%$ of probability $(\mathrm{p}<0.05)$.

The difference in soluble solids found between the cultivars in the Western Mesoregion of Rio Grande do Norte State may be related to the characteristics of each cultivar and the bulb maturation degree used in the analysis, since the starch is hydrolyzed and complex sugars are transformed into simple sugars with ripening (MATOS, 2007). Moreover, the values of soluble solids may vary depending on the environment and crop practices employed before, during and after harvest (OLIVEIRA et al., 2003; CHITARRA;
CHITARRA, 2005; BECKLES, 2012). Prati et al. (2010) studying qualitative characteristics of garlic cultivars (Roxinho, Santa-Catarina-Roxo, Commercial (Chines), Gigante-de-Curitibanos and Assai), found values of soluble solids between 30.83 and $33.84 \%$, which are lower than the maximum points found in this study.

The contents of total soluble sugars, differently from the other characteristics evaluated, were not affected by vernalization periods. BRSHozan had the highest percentages of total soluble 
sugars in both Barauna and Governador Dix-sept Rosado. Gigante-do-Nucleo had its highest amount of sugars in Governador Dix-sept Rosado, while
BRS-Hozan had its highest amount of sugars in Barauna, however, no significant differences were found between the two locations (Table 4).

Table 4. Average values of total soluble sugars (\%) of vernalizated semi-noble garlic cultivars in Barauna RN and Governador Dix-sept Rosado RN, Brazil.

\begin{tabular}{lcc}
\hline Cultivars & \multicolumn{2}{c}{ Planting locations } \\
\cline { 2 - 3 } & Barauna RN & Gov. Dix-sept Rosado RN \\
\hline Gigante-do-Nucleo & 13.45 & 17.63 \\
BRS-Hozan & 23.44 & 22.04 \\
\hline Minimum significant difference between cultivars $=2.63$. Student's t-test (LSD), $\mathrm{p}<0.05$. \\
Minimum significant difference between planting locations $=2.63$. Student's t-test (LSD), $\mathrm{p}<0.05$. \\
\hline
\end{tabular}

In general, the average sugar values in vegetables are from 2 to $5 \%$, according Chitarra e Chitarra (2005). Based on this information, garlic can be considered as rich in sugars, since it can present percentages higher than $20 \%$. This information is also confirmed by Soares (2013), who found sugar percentages ranging from 20.42 to $28.48 \%$, which were higher than those found for the cultivars Gigante-do-Nucleo and BRS-Hozan.

Regarding the reducing sugars, there was significant variations depending on vernalization periods only for BRS-Hozan, which had the highest values in Barauna with 20 DV. BRS-Hozan had the highest average of reducing sugars in Governador Dix-sept Rosado with 30 DV (Table 3). Chagas et al. (2003) found values lower than these, ranging from 0.21 to $0.48 \%$, while Prati et al. (2010) found higher values, ranging from 5.17 to $11.64 \%$.

Stringheta e Menezes Sobrinho (1986) reported that the presence of reducing sugars, even at relatively low levels, can influence the quality of dehydrated garlic. Reducing sugars such as glucose and fructose in the raw material under heating during drying, may be caramelized, changing the color of the dried garlic, and its functional properties, such as solubility, which can drastically reduce the acceptance and use of this dehydrated product.

Therefore, the low values of these sugars found in the present study may be an advantage compared to those from other researchers, such as Prati et al. (2010) who found higher values, confirming that Gigante-do-Nucleo and BRS-Hozan can be interesting cultivars when the final product is dehydrated garlic. The cultivar BRS-Hozan can be used to obtain black garlic due to its higher levels of reducing sugars compared to the Gigante-do-Nucleo. Previous studies reported that the antioxidant activity of black garlic is increased six-fold compared to the fresh produce (MACEDO et al., 2011).

Regarding the pungency depending on vernalization periods, both cultivars were influenced in both planting locations, presenting highest values in Barauna (Table 3). Gigante-do-Nucleo had the highest pungency averages in treatments without vernalization and with 10 and $20 \mathrm{DV}$ in Barauna, however, the latter had no statistical difference from the DV 30. In Governador Dix-sept Rosado, this cultivar also had the highest averages in these treatments, however, the treatment without vernalization and with $20 \mathrm{DV}$ had no difference from the $30 \mathrm{DV}$, which had the lowest average. On the other hand, BRS-Hozan had the highest pungency values in Barauna with 10 and $30 \mathrm{DV}$, and in Governador Dix-sept Rosado with treatments without vernalization and with 10 and $30 \mathrm{DV}$.

Significant differences in pungency were found between cultivars in Barauna with treatments without vernalization and with 10 and $20 \mathrm{DV}$, where the Gigante-do-Nucleo stood out with 95.59, 97.21 and $90.98 \mu \mathrm{Mol} \mathrm{mL}^{-1}$, respectively. Gigante-doNucleo presented the highest values in Governador Dix-sept Rosado in treatment with $20 \mathrm{DV}$, which was also higher than the BRS-Hozan (Table 3). Soares (2013) evaluate cultivars from the same group in Governador Dix-Sept Rosado without vernalization and found pungency from 86.15 to 95.78 $\mu \mathrm{Mol} \mathrm{mL} \mathrm{mL}^{-1}$, which were higher than those found with vernalizated garlic cultivars in the same place in the present study. These variations in results may be related to the genotype $\mathrm{x}$ environment interaction, which according to Vargas et al. (2010) strongly influences the pungency.

According to Feimberg (1973), the greater the raw material pungency, the higher the pungency of the finished product, ie, bulbs with higher pyruvic acid content result in industrial products with better characteristics of flavor and aroma, which is desired by consumers. The high soluble solids and the sharp and distinctive odor in garlic is essential for industrial purposes and for consumption in natura, since it is basic used as flavoring agent (BOTREL; OLIVEIRA 2012).

The total solid contents depending on vernalization periods presented increasing values for both cultivars in Barauna (Figure 2A). In Governador Dix-sept Rosado, the cultivar Gigantedo-Nucleo had decreasing values of total solid contents up to about $20 \mathrm{DV}$, and from there it had an increase with vernalization, while BRS-Hozan had total solid contents increasing with the increase in vernalization period (Figure 2B). The BRS-Hozan stood out in both planting locations, reaching maximum estimated values of total solids of $41.19 \%$ in Barauna, and $37.23 \%$ in Governador Dix-sept 
Rosado with 30 DV. The cultivar Gigante-do-Nucleo had maximum estimated values of $33.00 \%$ in Barauna and $32.55 \%$ in Governador Dix-Sept Rosado with 30 DV. Soares (2013) found total solids percentages ranging from 28.47 to $36.23 \%$, which were lower than the maximum found for the cultivars Gigante-do-Nucleo and BRS-Hozan in the present

A

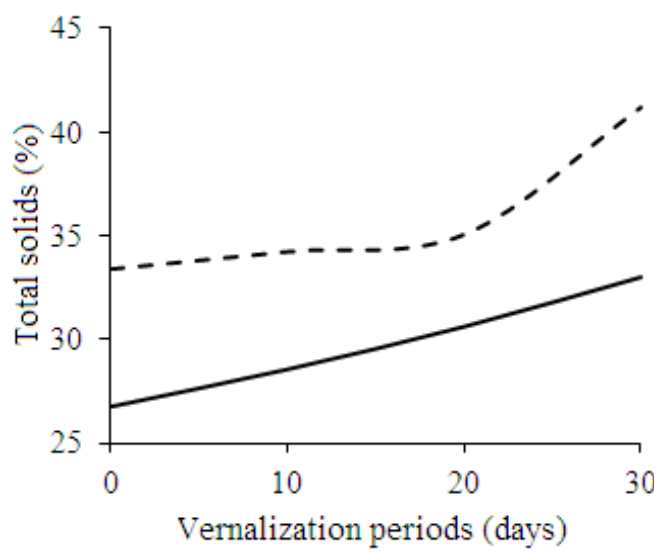

Gigante-do-Nucleo

$\hat{\mathrm{y}}^{-1}=0.0373^{*}-0.0002 * \mathrm{x} \quad \mathrm{R}^{2}=0.98^{*}$

- - - BRS-Hozan

$\hat{y}=33.3500 *+0.0840 * x+0.0000 * e^{x} \quad R^{2}=0.99 *$ study. According to Stringheta e Menezes Sobrinho (1986), high contents of total solids provide greater industry yields, therefore, it is a desirable characteristic for processing garlic. Thus, the cultivars produced in Barauna with bulb-seed vernalization have good prospects for industrialization.

$\mathrm{B}$

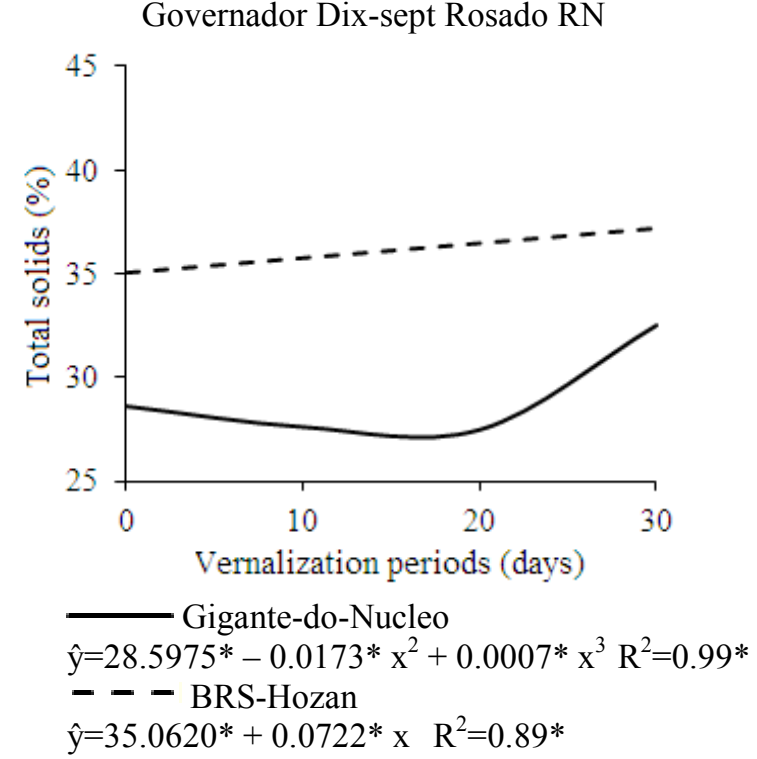

Figure 2. Total solids of vernalizated semi-noble garlic cultivars in Barauna RN (A) and Governador Dix-sept Rosado RN (B), Brazil. $*=$ significant at $5 \%$ of probability $(\mathrm{p}<0.05)$.

Regarding the industrial index depending on vernalization periods, the cultivar Gigante-doNucleo presented the highest averages in Barauna with treatments with 10 and $30 \mathrm{DV}$, however not significantly differing from the treatment with 20 DV. The treatment with $20 \mathrm{DV}$ was similar to the one without vernalization, which had industrial index was 25.42. In Governador Dix-Sept Rosado, this cultivar had similar industrial index between treatments, with average of 22.66. BRS-Hozan had the largest industrial index in Barauna with $30 \mathrm{DV}$, and in Governador Dix-sept Rosado without vernalization and with 10 and $30 \mathrm{DV}$, from which the first two had no difference from the treatment with $20 \mathrm{DV}$, which presented the lowest industrial index (Table 3).

Regarding the cultivars in each vernalization period and planting locations, the cultivar BRSHozan stood out in Barauna in the treatments with 10 and $30 \mathrm{DV}$, with industrial index of 30.68 and 36.67 , respectively. In Governador Dix-sept Rosado, significant differences between cultivars were observed in all treatments, with BRS-Hozan presenting the largest industrial index (Table 3). Chagas et al. (2003) found values lower than those in the present study, with industrial index from 17.17 to 21.03. The industrial index is a very important characteristic for dehydrated garlic, which result from the relationship between total solids and pyruvic acid. Therefore, garlic with high contents of total solids and pyruvic acid (pungency) present higher industrial index and better quality for dehydration.

These results confirm that the garlic quality vary with cultivar, environmental conditions and crop practices (including the techniques used). Studies on garlic composition is fundamental, since characteristics such as taste and especially smell contribute to the acceptance of this vegetable as a condiment, whether in natura or industrialized.

\section{CONCLUSIONS}

The use of 10-day bulb-seed pre-planting vernalization provided increases in the semi-noble garlic quality produced in Barauna and Governador Dix-sept Rosado.

The garlic produced in Barauna had larger diameters, pungency, total solids and industrial index and therefore better quality for processing or dehydration.

The cultivars Gigante-do-Nucleo and BRSHozan present good prospects for industrialization, with good characteristics of flavor and aroma. 


\section{ACKNOWLEDGEMENTS}

The authors thank the Brazilian National Council for Scientific and Technological Development (CNPq) for the financial support, and the Farms Santa Luzia (Barauna RN) and Santana (Governador Dix-sept Rosado RN) for the logistical support to carry out this research project.

\section{REFERENCES}

ALLEN, R. G. et al. Crop evapotranspiration: guidelines for computing crop water requirements. Rome: FAO, 1998. 297 p. (Irrigation and Drainage Paper, 56).

ASSOCIATION OF OFFICIAL ANALYTICAL CHEMISTRY - AOAC. Official methods of analysis of the Association of Official Analytical Chemistry. 17th ed. Washington: AOAC, 2002. $1115 \mathrm{p}$.

BOTREL, N.; OLIVEIRA, V. R. Cultivares de cebola e alho para processamento. In: CONGRESSO BRASILEIRO DE OLERICULTURA, 52, 2012, Salvador. Anais... Brasília: Associação Brasileira de Horticultura, 2012. p. S8420-S8434.

BECKLES, D. M. Factors affecting the postharvest soluble solids and sugar content of tomato (Solanum lycopersicum L.) fruit. Postharvest Biology and Technology, Amsterdam, v. 63, n. 1, p. 129-140, 2012.

CARVALHO, V. D. et al. Tempo de armazenamento na qualidade do alho cv. Amarante. Pesquisa Agropecuária Brasileira, Brasília, v. 26, n. 10, p. 1679-1684, 1991.

CAVAlCANTI, F. J. A. Recomendações de adubação para o estado de Pernambuco: $2^{\mathrm{a}}$ aproximação. 3. ed. Recife, PE: Instituto Agronômico de Pernambuco, 2008. 212 p.

CHAGAS, S. J. R.; RESENDE, G. M.; PEREIRA, L. V. Características qualitativas de cultivares de alho no Sul de Minas Gerais. Ciência e Agrotecnologia, Lavras, Sup., p. 1584-1588, 2003.

Chitarra, M. I. F.; Chitarra, A. B. Póscolheita de frutas $\mathrm{e}$ hortaliças: fisiologia $\mathrm{e}$ manuseio. 2. ed. Lavras, MG: UFLA, 2005. 783 p.

EMBRAPA. Sistema brasileiro de classificação de solos. 2. ed. Rio de Janeiro, RJ: EMBRAPA Solos, 2006. 306 p.

FEIMBERG, B. Vegetables. In: ARSDEL, W. B. V.;
COPLEY, M. J.; MORGAN JÚNIOR, A. I. (Eds.). Food Dehydratation. New York: AVI, 1973. v. 2, p. 43-55.

FERREIRA, D. F. SISVAR Versão 5.3 . Departamento de Ciências Exatas. Lavras-MG: UFLA, 2007.

GUTIERREZ, A. S. D.; ROCHA, I. L. A produção de alho no Brasil. Nosso Alho, Brasília, n. 19, p. 30$31,2014$.

HONORATO, A. R. F. et al. Avaliação de cultivares e alho na região de Mossoró. Revista Caatinga, Mossoró, v. 26, n. 3, p. 80-88, 2013.

INSTITUTO ADOLFO LUTZ - IAL. Métodos físico-químicos para análise de alimentos. 4. ed. São Paulo, SP: IAL, 2005. 533 p.

JANDEL SCIENTIFIC. Table Curve: curve fitting software. Corte Madera, CA: Jandel Scientific, 1991. $280 \mathrm{p}$.

LUCINI, M. A. Situação fitossanitária do alho no Brasil. Nosso Alho, Brasília, n. 19, p. 22-29, 2014.

MACÊDO, F. S.; SOUZA, R. J.; SILVA, E. C. Exigências climáticas. In: SOUZA, R. J.; MACÊDO, F. S. (Eds.). Cultura do alho: tecnologias modernas de produção. Lavras: UFLA, 2009. cap. 3, p. 29-38.

MACEDO, T. C. et al. Effect of process conditions on aged black garlic. In: 2ND INTERNATIONAL ISEKI_FOOD CONFERENCE, 2., 2011, Milan. Anais... Lisboa: ESB, 2011. p. 226-226.

MATOS, C. B. Caracterização física, química, físico-química de cupuaçus (Theobroma grandiflorum (Willd. Ex. Spreng) Schum.) com diferentes formatos. 2007. 41 f. Dissertação (Mestrado em Produção Vegetal: Área de Concentração em Produção Vegetal) - Universidade Estadual de Santa Cruz, Ilhéus, 2007.

MILLER, G. L. Use of dinitrosalicylic acid reagent for determination of reducing sugar. Analytical Chemistry, Urbana, v. 31, n. 3, p. 426-428, 1959.

MOTA, J. H. et al. Características físico-químicas de cultivares de alho (Allium sativum L.) do grupo semi -nobre, nas condições de Lavras, MG. In: CONGRESSO BRASILEIRO DE OLERICULTURA, 43., 2003, Recife. Anais... Brasília: Associação Brasileira de Horticultura, 2003. 1 CD-ROM.

MUELLER. S.; BIASI, J. Comportamento de cultivares de alho no Planalto Catarinense. Horticultura Brasileira, Brasília, v. 7, n. 1, p. 7-9, 
1989.

OLIVEIRA, C. M. et al. Determinação do ponto de colheita na produção de alho. Horticultura Brasileira, Brasília, v. 21, n. 3, p. 506-509, 2003.

OLIVEIRA, F. L. et al. Características agronômicas de cultivares de alho em Diamantina. Horticultura Brasileira, Brasília, v. 28, n. 3, p. 355-359, 2010.

PEREIRA, A. J.; SOUZA, R. J.; PEREIRA, W. R. Competição de cultivares de alho vernalizado na região de Inconfidentes-MG. In: CONGRESSO BRASILEIRO DE OLERICULTURA, 43., 2003, Recife. Anais... Brasília: Associação Brasileira de Horticultura, 2003. 1 CD-ROM.

PRATI, P.; HENRIQUE, C. M.; MARTINS, C. P. C. C. Caracterização físico $\square$ química de cultivares de alho. Pesquisa e Tecnologia, Campinas, v. 7, n. 15, p. 1-6, 2010.

RESENDE, F. V.; DUSI, A. N.; MELO, W. F. Recomendações básicas para a produção de alho em pequenas propriedades. Brasília: Embrapa/ CNPH, 2004. 12 p. (Comunicado Técnico, 22).

SCHWIMMER, S.; WESTON, W. J. Enzimatic development of pyruvicacid in onion as a measare of pungency. Journal of Agricultural and Food Chemistry, Washington, v. 4, n. 9, p. 303-304, 1961.

SCOTTON, D. C. Otimização do cultivo in vitro visando a transformação genética das cultivares brasileiras de alho (Allium sativum L.). 2007. 102 f. Dissertação (Mestrado em Ciências: Área de Concentração em Biologia na Agricultura e no Ambiente) - Universidade de São Paulo, Piracicaba, 2007.

SILVA, E. C.; SOUZA, R. J.; SANTOS, V. S. Efeitos do tempo de frigorificação em cultivares de alho (Allium sativum L.) provenientes de cultura de meristemas. Ciência e Agrotecnologia, Lavras, v. 24, n. 4, p. 939-946, 2000.

SOARES, A. M. Avaliação de cultivares de alho no município de Governador Dix-sept RosadoRN. 2013. 104 f. Dissertação (Mestrado em Fitotecnia: Área de Concentração em Agricultura Tropical) - Universidade Federal Rural do SemiÁrido, Mossoró, 2013.

STRINGHETA, P. C.; MENEZES SOBRINHO, J. A. Desidratação do alho. Informe Agropecuário, Belo Horizonte, v. 12, n. 142, p. 50-55, 1986.

VARGAS, S. et al. Efecto de la interacción genotipoambiente sobre la expresión del contenido de allicina y ácido pirúvico en ajo (Allium sativum L.). Revista
FCA UNCuyo, Mendonza, v. 42, n. 2, p. 15-22, 2010 .

YEMM, E. W.; WILLIS, A. J. The estimation of carbohydrates in plant extracts by anthrone. Biochemical Journal, London, v. 57, n. 3, p. 508$514,1954$. 